\title{
Forages with condensed tannins - their management and nutritive value for ruminants
}

\author{
G.C. WAGHORN, G.B. DOUGLAS, J.H. NIEZEN, W.C. McNABB and A.G. FOOTE \\ AgResearch, Grasslands Research Centre, Private Bag 11008, Palmerston North
}

\begin{abstract}
Temperate forage legumes that contain condensed tannins (CT) have been evaluated under experimental conditions and some have demonstrated significant benefits for sheep, cattle and deer. Condensed tannins can significantly improve productive performance, as well as lessen our dependence on anthelmintic drenches. However, not all CT are equal and some may not benefit production at all. This paper summarises the performance responses of ruminants to $\mathrm{CT}$ in birdsfoot trefoil (Lotus corniculatus), lotus (Lotus pedunculatus), sulla (Hedysarum coronarium), sainfoin (Onobrychis viciifolia) and erect dorycnium (Dorycnium rectum), and indicates the requirements for successful establishment and management of these swards. All require specialist care, and few will compete with common pasture species in high-fertility situations, but the potential benefits of reduced anthelmintic requirements when sheep are fed sulla, and the lowered incidence of flystrike and improved weight gain, wool growth, milk production and ovulation rate attributable to the CT in birdsfoot trefoil, makes these attractive options for farmers. Lotus is a high quality feed for wet, acid, low-fertility soils and sainfoin may result in very good stock performance in dry regions. Annual dry matter yields of the five species outlined here range from about 10 to $25 \mathrm{t} / \mathrm{ha}$ and some of these forages will benefit producers who are prepared to manage these forages correctly.
\end{abstract}

Keywords: birdsfoot trefoil, condensed tannin, dorycnium, forage legume, lotus, ruminant nutrition, sainfoin, sulla

\section{Introduction}

Researchers at the AgResearch Grasslands campus and Massey University have shown that the condensed tannins (CT) in several temperate forages can have substantial benefits for ruminant animals (Waghorn et al. 1990, 1999). Detailed information of animal responses to the CT in Lotus spp. and sulla (Hedysarum coronarium) has been obtained when fed to sheep held indoors in pens (e.g., Waghorn \& Shelton 1995; Wang et al. 1996a; Stienezen et al. 1996) and from field trials (e.g., Douglas et al. 1995; Wang et al. 1996b). These benefits have included improvements in liveweight gain, fleece weight, ovulation rate, milk production and composition, and in the ability of sheep (e.g., Niezen $e t$ al. 1995) and deer (Hoskin 1998; Table 1) to tolerate and sometimes reduce gastro-intestinal worm numbers.

Table 1 Potential benefits ${ }^{\#}$ of condensed tannins in temperate forages for ruminants.

\footnotetext{
- Prevent bloat in cattle

- Reduces dags in sheep and flystrike

- Can increase rate and efficiency of liveweight gain

- Can increase wool growth $\left(11 \%\right.$ with $\left.\mathrm{BT}^{\mathrm{a}}\right)$

- $15 \%$ increase in milk production from sheep (with BT)

- High protein, low fat milk

- Can increase ovulation rate in sheep (with BT)

- Improved tolerance of nematode burdens in sheep and deer

- Reduces worm numbers in sheep fed sulla

\# Benefits do not apply to all types of condensed tannin

a Birdsfoot trefoil
}

It is well known overseas that excessive dietary CT can be detrimental to animal performance (Waghorn et al. 1998) and more recently it has been shown that there is considerable variation between types of CT in both their chemistry (Foo et al. 1997) and effects on ruminant digestion (Waghorn \& Shelton 1997). However, the extent to which some types of CT in temperate forages can benefit productivity of ruminants fed high quality forages provides good reasons for their inclusion into farming systems. The problem is that CT-containing legumes differ substantially from common legumes (clovers, lucerne) in their establishment, management and often persistence. These forages have not received the same intensive selection for improvement as clovers (or lucerne) and there are problems with suppression by weeds, persistence, susceptibility to overgrazing and in productivity. Selection programmes are being undertaken at AgResearch to improve the persistence of birdsfoot trefoil (Lotus corniculatus) and sulla (Douglas et al. 1998).

This paper brings together and summarises animal performance/nutrition data with agronomic information for five cultivars containing CT which may have value for New Zealand agriculture: 
Birdsfoot trefoil (Lotus corniculatus L.) cv. Grasslands Goldie

Lotus (Lotus pedunculatus Cav.) cv. Grasslands Maku

Sulla (Hedysarum coronarium L.) cv. Grasslands Aokau

Sainfoin (Onobrychis viciifolia Scop.)

Dorycnium (Dorycnium rectum L. Ser. In DC) unnamed selection.

The information has been summarised from published sources and experience gained by researchers at AgResearch Grasslands who have established these forages for experimental purposes over the past 15 years. Where possible the data have been sourced from New Zealand studies, in order to provide a basis for establishment and use on New Zealand farms.

\section{Condensed tannins and nutrition}

Our interest in CT stems from both metabolic and grazing studies. This group of compounds can have profound effects upon digestion, and absorption of nutrients, yet they do not appear to be digested themselves (Terrill et al. 1994). Of greatest importance is their ability to reduce the breakdown of plant proteins in the rumen so that more amino acids reach the intestine. This ability has the potential to alleviate one of the principal problems facing pasture-fed ruminants: that of an adequate protein supply to meet demands of high productivity. Although high-quality temperate grasses and legumes have a seemingly adequate protein content, the protein is vulnerable to degradation by the rumen micro-organisms so that only about $30 \%$ of ingested plant protein reaches the intestine for absorption. Much of the ammonia arising from protein degradation must be disposed of as urea, at a cost to the animal.

Condensed tannins reduce protein degradation in the rumen and increase the flow of amino acids to the intestine for absorption (Waghorn et al. 1987, 1994; McNabb et al. 1996; Table 2). Grazing studies with some forages containing CT confirm the benefits of improved protein nutrition. These studies are carried out by comparing performance with a similar forage having a lower concentration of CT, no CT (e.g., white clover or lucerne), or by diluting the concentration of $\mathrm{CT}$ by feeding a mixture of CT and non-CT materials (Table 3). An alternative method is to feed the forage containing CT and give some animals daily drenches of polyethylene glycol (PEG) which is able to preferentially bind with and remove the effects of CT. The PEG is an effective procedure for evaluating CT in nutrition studies, but gives confusing results when given to parasitised sheep (Niezen et al. 1998a).
Table 2 Contrasting effects of condensed tannins from two lotus species fed to sheep\#.

\begin{tabular}{|c|c|c|c|c|}
\hline & \multirow{2}{*}{\multicolumn{2}{|c|}{$\begin{array}{l}\text { Birdsfoot trefoil } \\
\text { Control PEG }\end{array}$}} & \multicolumn{2}{|c|}{ Maku lotus } \\
\hline & & & Control & PEG \\
\hline \multirow{3}{*}{$\begin{array}{l}\text { CT in the DM (\%) } \\
\text { DM intake (indoor trials; g/day) } \\
\text { DM digestibility (\%) }\end{array}$} & 3.1 & - & 6.6 & - \\
\hline & 980 & 990 & 970 & 1080 \\
\hline & 69 & 71 & 68 & 70 \\
\hline \multirow{4}{*}{$\begin{array}{l}\text { Nitrogen in the DM (\%) } \\
\mathrm{N} \text { digestibility (\%) } \\
\mathrm{N} \text { digested in the rumen } \\
\text { (\% of intake) }\end{array}$} & 2.7 & 2.7 & 3.8 & 3.8 \\
\hline & 70 & 78 & 66 & 81 \\
\hline & & & & \\
\hline & 12 & 18 & 2 & 29 \\
\hline \multirow{3}{*}{$\begin{array}{l}\text { Rumen ammonia }(\mathrm{mg} \mathrm{N} / \mathrm{l}) \\
\text { Rumen VFA }{ }^{\mathrm{b}}\left(\mathrm{mmol}^{\prime} / \mathrm{l}\right) \\
\text { Rumen water pool }{ }^{\mathrm{c}}(\mathrm{I})\end{array}$} & 266 & 379 & 175 & 468 \\
\hline & 132 & 136 & 65 & 96 \\
\hline & 2.9 & 2.5 & 3.3 & 2.6 \\
\hline \multirow{4}{*}{$\begin{array}{l}\text { Plant } \mathrm{N} \text { reaching } \mathrm{SI} \mathrm{I}^{\mathrm{b}}(\% \text { of intake) } \\
\text { Total } \mathrm{N} \text { reaching } \mathrm{SI} \text { ( } \% \text { of intake) } \\
\text { Percentage absorption } \\
\quad \mathrm{AA}^{\mathrm{b}} \text { from the } \mathrm{SI}\end{array}$} & 49 & 34 & 44 & 30 \\
\hline & 82 & 68 & 93 & 67 \\
\hline & & & & \\
\hline & 65 & 63 & 63 & 75 \\
\hline
\end{tabular}

\# Results based on seven datasets, summarised in Waghorn 1997

a PEG; Polyethylene glycol given at 50-100 g/day, to bind with and remove effects of $\mathrm{CT}$ from the diet

b Abbreviations: CT, condensed tannin; DM, dry matter; N, nitrogen; VFA, volatile fatty acids; SI, small intestine; AA, amino acids

$c$ Water pool is adjusted to equal voluntary intakes

The performance of sheep and cattle grazed on birdsfoot trefoil has been excellent (Table 3), and while good performances have been achieved with lotus and sulla, the CT in these forages does not always provide substantial nutritional benefits for the animals. These observations highlight the complexity of CT behaviour during digestion. In addition to protecting plant proteins from degradation in the rumen, the CT interfere with amino acid absorption from the small intestine. With birdsfoot trefoil the interference with intestinal function appears to be minimal, so benefits from increased protein flow are realised by the animal. Unfortunately, birdsfoot trefoil appears to be unique in this regard; the $\mathrm{CT}$ in lotus reduces fractional absorption of amino acids from the intestine, which is roughly equivalent to the improvement in amino acid flow from the rumen. Nutritionally, the CT in lotus is neither beneficial nor detrimental to production (Table 3).

The differences in effects of CT upon animal performance are due to both concentration and type. When CT exceed about $4-6 \%$ of dry matter (DM) in temperate forages they are likely to be detrimental, and some CT are more astringent (Mangan 1988) and detrimental to digestion than others (Waghorn et al. 1998; Table 4). Our understanding of these factors is weak, but CT from several forages are being chemically analysed in detail (Foo et al. 1997) so that we can begin to understand the ways which CT chemistry might affect rumen and intestinal function.

Despite the difficulties of interpreting potential benefits of $\mathrm{CT}$ for nutrition and production, these compounds have clear benefits for ruminants in other 
Table 3 Effect of condensed tannins (CT) on animal performance. Comparisons are based on similar forages without CT or on the same forage with and without daily administration of polyethylene glycol (PEG) to remove effects of CT.

\begin{tabular}{|c|c|c|c|c|}
\hline Feeding regimen & Control treatment & Animal species & Production response & Data source \\
\hline \multicolumn{5}{|c|}{ Lotus corniculatus (birdsfoot trefoil) } \\
\hline grazing & PEG drench & ewes & $15 \%$ more milk & Wang et al. $1996 \mathrm{~b}$ \\
\hline grazing & PEG drench & young sheep & $11 \%$ more wool & Wang et al. 1996c \\
\hline grazing & PEG drench & mature ewes & $19 \%$ more efficient wool growth & Min et al. 1998 \\
\hline grazing & graze lucerne & young sheep & $24 \%$ more LWG and wool weight & Douglas et al. 1995 \\
\hline grazing & graze ryegrass & young sheep & $40 \%$ less flystrike, $30 \%$ less dags & Leathwick \& Atkinson 1995 \\
\hline grazing & graze lucerne & heifers & $20 \%$ more LWG & Marten et al. 1987 \\
\hline \multicolumn{5}{|c|}{ Lotus pedunculatus (lotus) } \\
\hline grazing & PEG drench & sheep & $25 \%$ less LWG & Barry \& Duncan 1984 \\
\hline stall fed & PEG drench & sheep & $7 \%$ less wool & Waghorn et al. 1994 \\
\hline stall with ryegrass & PEG drench & young sheep & $5 \%$ more wool, $9 \%$ more LWG & Waghorn \& Shelton 1995 \\
\hline grazing & graze white clover & young sheep & $13 \%$ less LWG & John \& Lancashire 1981 \\
\hline grazing & graze white clover & young sheep & $12 \%$ less LWG, leaner carcass & Purchas \& Keogh 1984 \\
\hline \multicolumn{5}{|c|}{ Onobrychis viciifolia (sainfoin) } \\
\hline grazing & graze white clover & young sheep & $3 \%$ less LWG & John \& Lancashire 1981 \\
\hline grazing & graze lucerne & heifers & $19 \%$ more LWG & Marten et al. 1987 \\
\hline \multicolumn{5}{|c|}{ Hedysarum coronarium (sulla) } \\
\hline grazing & PEG drench & sheep & $10 \%$ less LWG & Terrill et al. 1992 \\
\hline grazing & PEG drench & young sheep & no effect on LWG & Douglas et al. 1999 \\
\hline grazing & graze lucerne & sheep & $50 \%$ less intestinal nematodes, & \\
\hline & & & daily LWG 125 vs - 29g/day & Niezen et al. 1995 \\
\hline grazing & graze lucerne sheep & sheep & $28 \%$ less intestinal nematodes, & Rohertso \\
\hline grazing & graze chicory & deer & $22 \%$ more LWG & Hoskin 1998 \\
\hline
\end{tabular}

respects (Table 1). For example, the $\mathrm{CT}$ in birdsfoot trefoil reduce the incidence of dags and flystrike in sheep (Leathwick \& Atkinson 1995); lotus and sulla CT might have similar effects on dagginess but their impact on flystrike has not been evaluated. The $\mathrm{CT}$ in lotus enable sheep to maintain high productivity in the presence of a worm burden and the $\mathrm{CT}$ in sulla reduce worm numbers (Niezen et al. 1995); however, the CT in birdsfoot trefoil offer little protection against high worm burdens (Robinson et al. 1995). Deer maintained good performance when fed sulla or birdsfoot trefoil when challenged with lung worm, while similar deer fed lucerne performed poorly (Hoskin 1998).

We have recently extended our investigations of CT into the production of high-quality silages; the hypothesis is that the $\mathrm{CT}$ will reduce proteolysis during ensiling and provide a high quality forage for feeding during periods of feed shortage (Niezen et al. 1998b), and forages containing CT can benefit soil and water quality because the $\mathrm{CT}$ reduce outputs of urinary nitrogen $(\mathrm{N})$ in favour of more slowly degraded faecal $\mathrm{N}$.

\section{Problems and benefits of forages containing CT}

This section summarises information about five forage species used in animal and agronomic trials at Palmerston North. These forages may have a place in farming systems, but their potential benefits need to be evaluated in relation to problems peculiar to each species.
Table 4 Effect of condensed tannins in temperate forages on rumen and intestinal function. These are generalised responses which will vary with diet quality.

\section{Rumen}

Low dietary concentrations of CT (to $5 \%$ of DM) with temperate

forages

- Reduced (20-40\%) ammonia concentration

- Reduced proteolysis of plant protein and apparent $\mathrm{N}$ digestion in the rumen

- Possible minor reductions in rate of fermentation

- Minimal effect on rumen pool size, turnover rate or voluntary intake

- No effect on digestibility of structural fibre

- Minimal effect on microbial outflow to the intestine

- Increased availability of AA for absorption from the small intestine

Medium dietary concentrations of CT (5-12\% of DM) with temperate forages

- Substantial reduction (30-70\%) in ammonia concentration

- Reduced proteolysis of plant protein and apparent $\mathrm{N}$ digestion in the rumen

- Depressed microbial growth

- Reduced rate of fermentation, slower turnover rate and large rumen pool size; $20-40 \%$ reduction in VFA concentration

- Reduced voluntary food intake (10-30\%)

- Minor reductions in structural fibre digestibility

- Reduced microbial flow to SI; reduced total AA flow to SI because of intake depression

\section{Intestine}

Low-medium dietary concentrations of CT (to $8 \%$ of DM)

- Mucous production increased to protect intestine

- Excess mucous slows movement of metabolites to enterocytes for absorption

- Some CT will remain associated with digesta constituents throughout intestine and inhibit enzymic hydrolysis

- Possible compensatory increase in enzyme secretion

- Delayed absorption so more metabolites absorbed in mid and distal intestine

- Small increase in endogenous protein losses

- Small (up to $20 \%$ ) reductions in apparent digestibility of amino acids

Abbreviations: $\mathrm{CT}$, condensed tannin; $\mathrm{N}$, nitrogen; $\mathrm{AA}$, amino acid; VFA, volatile fatty acid; SI, small intestine. 


\section{Birdsfoot trefoil (Lotus corniculatus L)}

Birdsfoot trefoil is a semi-erect, long-lived, perennial legume originating from Europe. It has a tap-root and is well suited to drought-prone, low-moderate fertility situations including acidic soils. A large number of cultivars are available with wide-ranging growth habits. In New Zealand seed is available for several cultivars originating mainly from the USA and for the New Zealand-bred cultivar, Grasslands Goldie.

\section{Uses}

Widely used in North and South America and Europe (Scott \& Charlton 1983) for grazing and to a lesser extent soil conservation. Good potential use for pastoral farming in New Zealand on the east coast of both islands and Central Otago, subject to improved establishment and seed availability. The species is also being used in seed mixtures to supply nitrogen to young pine plantations.

\section{Establishment}

Birdsfoot trefoil can be grown on light sandy loams through to stony, free-draining soils. General fertiliser requirements are not high, and lime should be applied only if soil $\mathrm{pH}$ is less than 5.5 . The area should be free of major weeds, especially rhizomatous species, and the soil cultivated to achieve a fine, well-compacted tilth. Best sown in spring; autumn sowings should be early, as winter growth is minimal. If sown as a pure sward, use $8-12 \mathrm{~kg} / \mathrm{ha}$ of inoculated/pelleted seed drilled $10-20 \mathrm{~mm}$ deep, or broadcast with a light harrow. An effective rhizobium strain is available and seed should be inoculated on the day of sowing. Birdsfoot trefoil could be sown with a low-moderate tillering grass, e.g., prairie grass or an erect cocksfoot, and rotationally grazed to prevent excessive selection of the lotus, and associated crown damage.

\section{Management}

Birdsfoot trefoil should be grazed leniently during the first year, under a rotational grazing regime. Ideally use mob stocking (also to control weeds) with 4- to 6week intervals between grazing to allow recovery (Bologna et al. 1996). Insufficient information is available to define sward life, but longevity would be enhanced by allowing some seeding in the first two years of stand life to establish a buried seed-bank. Although birdsfoot trefoil is relatively free from disease and pest damage in New Zealand, it has poor competitive capabilities and will not persist when ryegrasses and white clovers become dominant. For this reason it is unlikely to be grown in moist, highfertility situations.
Main growth periods are during spring and from mid summer through to late autumn. Yields have been measured from pure stands and can be $10-15 \mathrm{t} \mathrm{DM} / \mathrm{ha}$ under good growing conditions and careful management.

\section{Chemical composition and nutritive value}

Birdsfoot trefoil contains about 25-35 g N/kg DM (15$18 \%$ crude protein) which is substantially lower than white clover, lucerne and many grasses. The concentration of CT in the forage varies from virtually nil (cv. Empire; $0.2 \% \mathrm{DM}$ ) to about $4 \%$ of the DM. Values for Grasslands Goldie range from about $2.5-4.0 \%$ of the DM. Concentrations of soluble sugars and structural fibre depend stage of maturity and proportions of leaf and stem. Once the plant becomes mature, stems become very stringy and are rejected by sheep, so at least half of the DM is avoided and only the leaf is consumed. This can result in a very poor utilisation of the forage (Douglas et al. 1999). Grazing management must therefore be lenient and rotational to encourage persistence, but lax grazing and rejection of stem material must be avoided.

The CT in birdsfoot trefoil have very considerable benefits for ruminants because they protect plant protein from excessive microbial degradation in the rumen but do not inhibit absorption of amino acids from the intestine. This tannin appears to be unique among the tannin containing forages that have been studied, and experimental trials have demonstrated significant improvements in wool growth, milk production, liveweight gain, ovulation rate and reductions in incidence of dags and flystrike in sheep as a consequence of the CT in birdsfoot trefoil (Tables 2 and 3). Productivity of animals fed birdsfoot trefoil exceeds that of animals fed lucerne.

\section{Potential value}

The poor competitiveness of birdsfoot trefoil in pasture is being addressed at AgResearch Grasslands, but research is needed to evaluate appropriate companion species and their management under grazing in New Zealand. Erect types have good potential for producing high quality hay and silage, providing management can achieve good yields and persistence. The CT in birdsfoot trefoil are of great value for ruminant productivity but its usefulness is limited by the agronomic performance of the species.

Lotus, lotus major, big trefoil, marsh trefoil (Lotus pedunculatus Cav. syn. Lotus uliginosus Schkuhr)

Lotus is a prostrate, rhizomatous legume, tolerant of wet conditions and best suited to cold, acid, low-fertility soils. It originates from Europe where native lotuses are 
diploid, but cv. Grasslands Maku is tetraploid and is the most widely used commercial cultivar in New Zealand. Seed availability is good.

\section{Uses}

Principal uses are in plantation forestry as a nitrogen source (some in agroforestry) and it is incorporated in seed mixes for moist, low fertility, acid soils, e.g., Northland, Southland and moist hill country throughout. Increased availability of cv. Grasslands Goldie may lessen the use of lotus in plantation forestry, especially on dry sandy soils. Used in pastures in eastern New South Wales and southern Queensland, southern China, Andes and Himalayan regions.

\section{Establishment}

Although lotus often forms a major component of seed mixes for plantation forestry, it is a minor component of pasture seed mixes, complementing white clover in good rolling hill country with shady aspects. It can be compatible with ryegrass in low fertility situations but will not be competitive in high fertility environments. Grows well in heavy clay and damp environments but it is less tolerant of dry and possibly cold conditions than birdsfoot trefoil. Can be sown in spring or early autumn in well-cultivated and weed-free situations. Seed should be inoculated/pelleted and drilled or broadcast at 2-5 $\mathrm{kg} / \mathrm{ha}$ to a depth of $10 \mathrm{~mm}$ or less for a pure sward, or incorporated at about $2-3 \mathrm{~kg} / \mathrm{ha}$ into a pasture seed mix. Phosphate requirements are low but it will respond to topdressing.

\section{Management}

Plants are slow to develop so grazing should be restricted in the first year to encourage rhizome development in the late summer/autumn. Although it is rarely grown as a pure sward for grazing, in this situation grazing should be lax and infrequent, but when grown as a component of mixed pasture, normal management applies. Lotus has good persistence and productivity under appropriate conditions.

Dry matter production of pure swards range between $7-13 \mathrm{t} / \mathrm{ha}$, but it is difficult to maintain a pure stand under high fertility conditions because of competition from other species.

\section{Chemical composition and nutritive value}

Lotus contains about 28-40 g N/kg DM (17-24\% crude protein). Concentrations of CT are about $5-9 \%$ of the DM, with higher concentrations in leaf $(12 \%$ of the $\mathrm{DM}$ ), and concentrations increase when growing conditions are poor. Very palatable when young but mature stems are very tough and not eaten by sheep or cattle.
The digestibility of the DM is similar to that of birdsfoot trefoil (68-70\%), but the CT do not benefit overall nutrition. The CT provide good or excessive protection of plant proteins from degradation and loss from the rumen and this will increase the protein flow to the intestine, but the $\mathrm{CT}$ are detrimental to intestinal function and reduce the proportion of protein which is absorbed. When given as a sole diet the $\mathrm{CT}$ are likely to cause small but significant reductions in voluntary intakes because their impact upon rumen microbes reduces bacterial capacity for fibre digestion after 2-3 weeks of feeding.

Despite problems attributable to CT when this forage is given as a sole diet, it will provide excellent levels of productivity when fed with other forage species, albeit less than that from birdsfoot trefoil. It enables sheep to perform well in the face of a gastro-intestinal worm burden, minimises the accumulation of dags and prevents bloat in cattle.

\section{Potential value}

Lotus is widely known and used as a minor component of many pastures in New Zealand and overseas. Current research is attempting to develop a strain with better germination at low temperatures and there is renewed interest in crossing lotus with birdsfoot trefoil because lotus has better pest resistance and has a rhizomatous growth habit.

Sulla, French honeysuckle, Spanish sainfoin (Hedysarum coronarium L.)

Sulla is a short-lived perennial, often biennial, legume originating from the Mediterranean where it is used widely as a green feed, as well as for hay and silage (Douglas 1984). The plant grows, up to $1.5 \mathrm{~m}$ tall), has a well developed tap-root and is particularly suited to neutral-alkaline soils. It tolerates a wide range of rainfall (500-2000 mm pa) and has moderate winter growth in Manawatu and Canterbury. Growth at other times of the year can be spectacular. Plants have very attractive bright red or pink flowers for almost half of the year. Several cultivars are available; New Zealand selections include cv. Grasslands Aokau and cv. Necton. Grasslands Aokau is predominantly semi-erect and thick-stemmed whereas Necton is erect with thin stems and probably better suited for hay or silage production. Sulla has a better leaf retention than lucerne when dried and all parts of the plant are very palatable to livestock.

\section{Uses}

Widely grown in countries surrounding the Mediterranean and is an important animal forage in Italy but there is very limited use in New Zealand at present, 
although some is grown in Marlborough for fat lamb production. It was introduced to New Zealand for soil conservation in the mid 1950s and is useful for revegetating mudstone soils, especially in Wairarapa, Hawke's Bay and Taranaki, but these areas must be retired from livestock access or the species will be eaten out. Potential for livestock feeding is excellent because sulla can achieve very high dry matter yields of exceptionally palatable forage resulting in very high growth rates by lambs and deer, and a good level of anthelmintic activity.

\section{Establishment}

Soils should be well drained, with a pH of 6-8, and the site should be free of perennial weeds such as couch, yarrow and Californian thistle because sulla is susceptible to crowding both during establishment and following periodic harvests. A pre-emergence herbicide (e.g., trifluralin) is recommended. The seed-bed should be deeply worked and compacted with a fine tilth on the surface. Seed should be inoculated and lime pelleted and sown to $10-20 \mathrm{~mm}$ by drilling or broadcasting and lightly harrowed. Dehulled seed should be sown at 10 $12 \mathrm{~kg} / \mathrm{ha}$. Companion species are being investigated with a view to establishment with grasses having an open growth habit (phalaris, prairie grass). However, sulla is very susceptible to weed dominance because, after germinating and reaching about $150 \mathrm{~mm}$, it remains at this rosette stage for $4-5$ weeks (also post cutting) whilst developing several growth points. New growth is from the crown where leaves emerge rapidly (200-300 $\mathrm{mm}$ /week) after this dormancy.

\section{Management}

New stands should be grazed lightly with sheep once plants are well established (possibly 2-3 months after sowing), and all grazing should be rotational with large numbers of animals for a short period to minimise crown damage. Grazing is best during early stem elongation at about $10 \%$ flowering when plants are $500-800 \mathrm{~mm}$ tall; however, the stems are very palatable and most will still be eaten if the sward reaches $1 \mathrm{~m}$ or more. Plant recovery post grazing is slow; intervals of 3-4 months may be necessary between grazings. Recovery is probably better if herbage is conserved/cut for forage rather than grazed, and cutting may be preferable to flail harvesting. The protracted dormancy post harvest can result in major problems with weed ingression, but spraying with 1.51 glyphosate/ha has achieved good weed control and allowed excellent recovery by the sulla.

It must be emphasised that few data are available on sulla management, and some of the information presented here arises from methods used to produce sulla for experimental feeding trials, rather than rigorously enforced agronomic evaluations. Sulla should be allowed to set seed once every 2 years because most plants appear to persist for about 2, rather than 3 years; in very hot conditions sulla behaves as an annual.

Yields of $25 \mathrm{t} \mathrm{DM/ha/annum} \mathrm{have} \mathrm{been} \mathrm{achieved,}$ and may be higher with good management, especially when winter growth takes place. Sulla responds well to superphosphate and potash fertilisers.

\section{Chemical composition and nutritive value}

Sulla is a succulent forage, typically $14-18 \%$ DM in the field. It contains $22-30 \mathrm{~g} \mathrm{~N} / \mathrm{kg} \mathrm{DM}$, equivalent to 14 $18 \%$ crude protein, and a high concentration of soluble carbohydrate $(18 \%$ of $\mathrm{DM})$ relative to structural fibre. The concentration of CT in the herbage is typically about $8 \%$ of the DM (range $3-12 \%$ ), and they are concentrated in the leaf and flower rather than stem fractions. Flowers form a high percentage of the plant, ratios of leaf, stem and flower DM being about $28 \%, 52 \%$ and $20 \%$, respectively (Steinzen et al. 1997; Douglas et al. 1999). All fractions are readily eaten by sheep and deer, even when stems are about $10 \mathrm{~mm}$ in diameter.

Animal performance can be very good. Sulla fed as a sole diet to deer (Hoskin 1998) resulted in growth exceeding that with chicory, and newly weaned lambs have achieved daily gains of $340 \mathrm{~g}$. However, the concentration of CT is likely to inhibit protein digestion and absorption to an excessive amount, and anecdotal evidence suggests it should not be fed as a sole diet to lactating cattle. Insufficient research has been carried out to give firm recommendations about feeding, whether as a sole diet (for how long?) or whether it should be fed in conjunction with pasture. Field and indoor trials have not demonstrated benefits attributable to the $\mathrm{CT}$ per se (Table 3) despite the excellent growth of lambs and deer.

There is very good evidence to show that a sulla diet enables sheep and deer to perform well in the face of gastro-intestinal (and lung worm) burdens, and the numbers of parasites decline with a sulla diet relative to other forages.

\section{Potential value}

Very good for sheep and deer performance and parasite control as well as land stabilisation, roadside beautification and improving soil structure (the root system is estimated to be $20 \mathrm{t} \mathrm{DM} / \mathrm{ha}$ ). Currently evaluated for hay and silage production (Niezen et al. 1998b), future research needs to focus on integration with other forage species, management and seed processing. Existing technology causes excessive seed damage during hull removal and a new scarification process being developed at AgResearch aims to improve the yield of viable seed. 


\section{Sainfoin (Onobrychis viciifolia Scop.)}

Sainfoin is an erect, deep-rooted, perennial legume originating from the eastern Mediterranean. This plant has been documented for at least 2000 years and is used in the western United States, Canada and to a minor extent in the United Kingdom, but it is very rarely used in New Zealand. Sainfoin is extremely palatable and is resistant to some pests affecting lucerne (alfalfa weevil and aphid) and can be grown with lucerne. It is resistant to extreme cold but is susceptible to root rot and crown rot, so stand life is typically about 3 years.

\section{Uses}

Not important in New Zealand, but trials have shown excellent animal performance (McKinnon 1993) and the type of CT in sainfoin may not be detrimental to intestinal function. Single- and multiple-cut cultivars are available; the former (Eski, Melrose) are late flowering and suitable for high quality hay, whereas Remont, Fakir and Renumex have a more even yield throughout the growing season. Principal seed source is Canada and western USA; no New Zealand selections are available.

\section{Establishment}

Grows best in deep, well-drained and shallow gravely soils with $\mathrm{pH}>6.0$. The seed-bed should be free of rhizomatus weeds, and have been cultivated or cropped over winter then worked deeply to form a firm, fine, seed bed for sowing. Seed can be sown with hulls (40$50 \mathrm{~kg} / \mathrm{ha})$ or with hulls removed $(10-15 \mathrm{~kg} / \mathrm{ha})$ and drilled to $1-2 \mathrm{~cm} / \mathrm{depth}$. The seed should be innoculated/ pelleted but poor $\mathrm{N}$ fixation can occur in some instances. Where summers are dry, autumn sowing is recommended; mature plants are drought tolerant and respond to phosphate/potash fertilisers. Our limited current knowledge suggests sainfoin is best sown as a monoculture, but trials are underway in Canada where sainfoin is established with lucerne as a means to reduce the incidence of bloat in grazing cattle.

\section{Management}

Slow and expensive to establish and it is important that competition from weeds be minimised by mowing or grazing in the first year. Established plants regrow better when cutting or grazing is done after flowering, and digestibility remains high with mature forage. Stand life may be prolonged if cutting/grazing is limited to twice yearly, otherwise a depletion of root reserves appears to shorten stand life. Information about reseeding is not available, but sainfoin is easily smothered by weeds and it is not suitable for growing with pasture. Yields of 12-15 t DM/ha have been reported from early- flowering cultivars, but only $8 \mathrm{t} \mathrm{DM} / \mathrm{ha}$ in the United Kingdom. On pumice country sainfoin will yield 2 cuts cf. 3 from lucerne, but the very high quality of this legume and its ability to prevent bloat suggest that it might have a role in some situations, especially in view of its drought tolerance. Weed growth may be controlled by establishing with barley as a nurse crop, or if sown with timothy or fescue as companion species (Fearn 1987).

\section{Chemical composition and nutritive value}

Sainfoin comprises about $70 \%$ leaf in immature material and $50 \%$ leaf in mature stands; $\mathrm{N}$ content of immature sainfoin is about $34 \mathrm{~g} / \mathrm{kg} \mathrm{DM}$ ( $21 \%$ crude protein) and soluble carbohydrate content can exceed $20 \%$ of the DM. The CT comprise about $5-8 \%$ of the DM and may be less deleterious to digestion than those from lotus. Digestibility of the DM is about $70 \%$ and animal performance is similar to that of white clover, but the growth habit of sainfoin makes it more suited to dry, or drought-prone environments.

\section{Potential value}

The good yield, very high nutritive value and drought tolerance of this legume, with substantial use in North America, makes it a forage for consideration in parts of New Zealand. However, several topics need to be addressed in order to improve its value for farmers; these include improvement of DM yields, reduction in seed required for establishment and improvements in resistance to fungal disease. Poor competition with weeds is an important aspect of management and this species must not be overgrazed if a long stand life is desired.

Erect dorycnium (Dorycnium rectum L. Ser. in DC)

An erect, multi-branched, perennial shrub legume, with a well developed tap-root system originating from moderately moist regions of the Mediterranean (Portugal, Spain). Not appropriate for conservation in dry areas but is probably tolerant of low-fertility situations. If untrimmed grows to 3-4 m high, and regrowth occurs from the crown after cutting; lives for 10 years or longer.

\section{Uses}

Used only for experimental purposes in New Zealand, but is palatable to livestock and has some potential for use as a browse forage; when trimmed after reaching 60 cm, 3-4 cuts per year are possible, yields exceeding those for lucerne $(20$ vs 14 t DM/ha respectively; Douglas \& Foote 1994). 


\section{Establishment}

Either as seedlings or drilled in spaced rows; if left unchecked this forage could form a dense virtually impenetrable thicket. Sow at $10 \mathrm{~mm}$ depth; has established well in experimental situations. May be affected by silver leaf.

\section{Chemical composition and nutritive value}

Minimal experimental work has been undertaken, but erect dorycnium has about $50 \%$ leaf in the DM, and sheep will eat both leaf and stems to about $6 \mathrm{~mm}$ in diameter. Nitrogen content of leaf and stem are 3.0 and $0.8 \%$ respectively (18 and $5 \%$ crude protein). Very high concentration of CT in leaf $(19 \%$ of DM) results in a DM digestibility of only $60 \%$. This concentration of CT exceeds that which is beneficial for ruminants, but this forage could form an excellent source of feed materials when feed shortages occur (Douglas et al. 1996).

\section{Summary}

These legumes, all of which contain CT, are very palatable to livestock, and some may enable very good performance, even in the face of a parasite burden. However, all the species require specialised treatment in terms of both establishment and management and all have weaknesses in terms of either yield or persistence (Frame et al. 1998). Birdsfoot trefoil possesses a CT which greatly improves utilisation of nutrients and results in excellent animal performance, but stems can become inedible and DM yields are relatively low. Lotus is an excellent species for moist environments, but the CT does not benefit digestion and the species should be fed with non-CT forages to lessen the impact. Sulla has a spectacular yield of DM, can reduce the need for proprietary anthelmintics and needs very specialised management. Sainfoin has similar attributes to lucerne but is usually less productive and stand life is only 2-3 years. Erect dorycnium can have a very high forage yield but is a virtual unknown in terms of animal performance.

This paper has attempted to highlight both the benefits and the problems associated with each forage, and although problems may appear significant, the animal performance that can be achieved merits more agronomic investigation involving establishment, weed control, harvesting and disease resistance. If agronomic selection is allowed to continue, some of these forages may rival or exceed those like lucerne and raise the productivity of our sheep and cattle above their current mediocre levels.

\section{REFERENCES}

Barry, T.N.; Duncan, S.J. 1984. The role of condensed tannins in the nutritional value of Lotus pedunculatus for sheep. 1. Voluntary intake. British journal of nutrition 51: 484-491.

Bologna, J.J.; Rowarth, J.S.; Fraser, T.J.; Hill, G.D. 1996. Management of birdsfoot trefoil (Lotus corniculatus L) pastures for productivity and persistence. Proceedings of the Agronomy Society of New Zealand 26: 17-21.

Douglas, G.B. 1984. Seed production of sulla - a plant for soil conservation. Proceedings of the New Zealand Grassland Association 45: 239-242.

Douglas, G.B.; Foote, A.G. 1994. Establishment of perennial species useful for soil conservation and as forages. New Zealand journal of agricultural research 37: 1-9.

Douglas, G.B.; Wang, Y.; Waghorn, G.C.; Barry, T.N.; Purchas, R.W.; Foote, A.G.; Wilson, G.F. 1995. Liveweight gain and wool production of sheep grazing Lotus corniculatus and lucerne (Medicago sativa). New Zealand journal of agricultural research 38: 95-104.

Douglas, G.B.; Bulloch, B.T.; Foote, A.G. 1996. Cutting management of willows (salix spp.) and leguminous shrubs for forage during summer. New Zealand journal of agricultural research 39: 175-184.

Douglas, G.B.; Keogh, R.G.; Foote, A.G. 1998. Development of a more grazing tolerant line of sulla (Hedysarum coronarium). Proceedings of the New Zealand Grassland Association 60: 173-179.

Douglas, G.B.; Stienezen, M.; Waghorn, G.C.; Foote, A.G.; Purchas, R.W. 1999. Effect of condensed tannins in birdsfoot trefoil (Lotus corniculatus) and sulla (Hedysarum coronarium) on body weight, carcass fat and wool growth of lambs. New Zealand journal of agricultural research 42: 55-64.

Fearn, L.M. 1987. Sainfoin. Biologist 34: 93-97.

Foo, L.Y.; Lu, Y.; McNabb, W.C.; Waghorn, G.C.; Ulyatt, M.J. 1997. Proanthocyanidins from Lotus pedunculatus. Phytochemistry 45: 1689-1696.

Frame, J.; Charlton, J.F.L.; Laidlaw, A.S. 1998. Temperate forage legumes. Wallingford, CAB International.

Hoskin, S.O. 1998. Internal parasitism and growth of farmed deer fed different forage species. $\mathrm{PhD}$ thesis, Massey University, Palmerston North.

John, A.; Lancashire, J.A. 1981. Aspects of the feeding and nutritive value of Lotus species. Proceedings of the New Zealand Grasslands Association 42: 152159. 
Leathwick, D.M.; Atkinson, D.S. 1995. Dagginess and flystrike in lambs grazed on Lotus corniculatus or ryegrass. Proceedings of the New Zealand Society of Animal Production 55: 196-198.

Mangan, J.L. 1988. Nutritional effects of tannins in animal feeds. Nutrition research reviews 1: 209232.

Marten, G.C.; Ehle, F.R.; Ristan, E.A. 1987. Performance and photosensitisation of cattle related to forage quality of four legumes. Crop science 27: 138-145.

Min, B.R.; Barry, T.N.; McNabb, W.C.; Kemp, P.D. 1998. Effect of condensed tannins on the production of wool and on its processing characteristics in sheep grazing Lotus corniculatus. Australian journal of agricultural research 49: 597-605.

McKinnon, D. 1983. Sainfoin: A non-bloating legume which could have a role. New Zealand farmer 24: 21-24.

McNabb, W.C.; Waghorn, G.C.; Peters, J.S.; Barry, T.N. 1996. The effect of condensed tannins in Lotus pedunculatus on the solubilisation and degradation of ribulose-1, 5-bisphosphate carboxylase (EC 4.1.1.39; Rubisco) protein in the rumen and sites of Rubisco digestion. British journal of nutrition 76: 535-549.

Niezen, J.H.; Waghorn, T.S.; Charleston, W.A.G.; Waghorn, G.C. 1995. Growth and gastrointestinal nematode parasitism in lambs grazing either lucerne (Medicago sativa) or sulla (Hedysarum coronarium) which contains condensed tannins. Journal of agricultural science, Cambridge 125: 281-289.

Niezen, J.H.; Waghorn, G.C.; Charleston, W.A.G. 1998a. Establishment and fecundity of Ostertagia circumcincta and Trichostrongylus colubriformis in lambs fed lotus (Lotus pedunculatus) or perennial ryegrass (Lolium perenne). Veterinary parasitology 78: 13-21.

Niezen, J.N.; Waghorn, G.C.; Lyons, T.B.; Corson, D.C. 1998b. The ensiling capabilities of sulla (Hedysarum coronarium) related to pasture. Proceedings of the New Zealand Grassland Association 60: 105-109.

Purchas, R.W.; Keogh, R.G. 1984. Fatness of lambs grazed on 'Grasslands Maku' lotus and 'Grasslands Huia' white clover. Proceedings of the New Zealand Society of Animal Production 44: 219-221.

Robertson, H.A.; Niezen, J.H.; Waghorn, G.C.; Charleston, W.A.G.; Jinlong, M. 1995. The effect of six herbages on liveweight gain, wool growth and faecal egg count of parasitised ewe lambs. Proceedings of the New Zealand Society of Animal Production 55: 199-201.
Scott, D.; Charlton, J.F.L. 1983. Birdsfoot trefoil (Lotus corniculatus) as a potential dryland herbage legume in New Zealand. Proceedings of the New Zealand Grassland Association 44: 98-105.

Stienzen, M.; Waghorn, G.C.; Douglas, G.B. 1996. Digestibility and effects of condensed tannins on digestion of sulla (Hedysarum coronarium) when fed to sheep. New Zealand journal of agricultural research 39: 215-221.

Terrill, T.H.; Waghorn, G.C.; Woolley, D.S.; McNabb, W.C.; Barry, T.N. 1994. Assay and digestion of ${ }^{14} \mathrm{C}$-labelled condensed tannins in the gastrointestinal tract of sheep. British journal of nutrition 72: 467477.

Waghorn, G.C.; Shelton, I.D. 1995. Effect of condensed tannins in Lotus pedunculatus on the nutritive value of ryegrass (Lolium perenne) fed to sheep. Journal of agricultural science, Cambridge 125: 291-297.

Waghorn, G.C.; Shelton, I.D. 1997. Effect of condensed tannins in Lotus corniculatus on the nutritive value of pasture for sheep. Journal of agricultural science, Cambridge 128: 365-372.

Waghorn, G.C.; Reed, J.D.; Ndlovu, L.R. 1999. Condensed tannins and herbivore nutrition. pp. 153166. In: Proceedings of the XVIII International Grasslands Congress. Buchanan-Smith, J.G.; Bailey, L.D.; McCaughey, P. (eds.) Association Management Centre, Calgary, Alberta.

Waghorn, G.C.; Jones, W.T.; Shelton, I.D.; McNabb, W.C. 1990. Condensed tannins and the nutritive value of herbage. Proceedings of the New Zealand Grassland Association 51: 171-176.

Waghorn, G.C.; Ulyatt, M.J.; John, A.; Fisher, M.T. 1987. The effect of condensed tannins on the site of digestion of amino acids and other nutrients in sheep fed on lotus. British journal of nutrition 57: 115126.

Waghorn, G.C.; Shelton, I.D.; McNabb, W.C.; McCutcheon, S.N. 1994. Effects of condensed tannins in Lotus pedunculatus on its nutritive value for sheep. 2. Nitrogenous aspects. Journal of agricultural science, Cambridge 123: 109-119.

Wang, Y.; Waghorn, G.C.; McNabb, W.C.; Barry, T.N.; Hedley, M.J.; Shelton, I.D. 1996a. Effect of condensed tannins in Lotus corniculatus upon the digestion of methionine and cysteine in the small intestine of sheep. Journal of agricultural science, Cambridge 127: 413-421.

Wang, Y.; Douglas, G.B.; Waghorn, G.C.; Barry, T.N.; Foote, A.G. 1996b. Effect of condensed tannins in Lotus corniculatus upon lactation performance in ewes. Journal of agricultural science, Cambridge 126: 353-362. 
Wang, Y.; Douglas, G.B.; Waghorn, G.C.; Barry, T.N.; Foote, A.G.; Purchas, R.W. 1996c. The effect of condensed tannins upon the performance of lambs grazing Lotus corniculatus and lucerne (Medicago sativa). Journal of agricultural science, Cambridge 126: 87-98. 